\title{
PERANCANGAN ORNAMEN "HARINI" MELALUI KAJIAN VISUAL RELIEF LATITAVISTARA PADA CANDI BOROBUDUR
}

\author{
Noor Latif CM \\ Creative Advertising Department, School of Design, BINUS University \\ Jln. K.H. Syahdan No. 9, Palmerah, Jakarta Barat 11480 \\ lateevhaq@gmail.com
}

\begin{abstract}
Indonesia has many ornaments given that various cultures born in this archipelago. Variety of ornaments that characterizes a region refers to such cultural relics from the past. Excavation of the ornaments through the relics of the past with a rich in visual such as Borobudur may lead to the birth of the spirit of love of local product which is based on culture and tradition. Latitavistara relief which is part of the past Buddhist fragment became the main object in extracting visual object to bear a new visual language in the form of ornaments. The design of the ornament with a new visual appearance only used the visual elements of the flora in Latitavistara relief classified according to its clump type. The method used in this visual design referred to the simplification of the form leading to the symbolization inherent to the religious philosophy of Borobudur. Division levels in the pursuit of perfection contained in Borobudur were basis for determining the variations of ornament design generated. The results of this ornament design are expected to be applied into other visual disciplines which is not always be just a mere craft product. The spirit of recycling cultural heritage and traditions of the past to be a creative product with modern innovation becomes inseparable part of this design.
\end{abstract}

Keywords: design, ornament, Borobudur

\begin{abstract}
ABSTRAK
Ornamen banyak dimiliki oleh bangsa Indonesia mengingat beragam budaya lahir di kepulauan nusantara ini. Ragam ornamen yang yang menjadi ciri khas suatu daerah mengacu pada peninggalan budaya rupa masa lalu. Penggalian ornamen melalui peninggalan masa lalu yang kaya dengan perbendaharaan visual, seperti Candi Borobudur, dapat menjadi pemicu lahirnya semangat mencintai produk lokal yang berbasis budaya dan tradisi. Relief Latitavistara yang adalah bagian dari fragmen Budhis masa lalu menjadi objek utama dalam penggalian obyek visual untuk melahirkan bahasa rupa baru dalam bentuk ornamen. Perancangan ornamen dengan tampilan visual baru hanya memanfaatkan unsur visual flora dalam relief Latitavistara yang diklasifikasikan sesuai dengan rumpun jenisnya. Metode yang digunakan dalam perancangan ini mengacu pada penyederhanaan bentuk visual yang mengarah pada simbolisasi yang melekat dalam filosofi spiritual Borobudur. Pembagian tingkatan dalam mencapai kesempurnaan yang terdapat dalam Candi Borobudur menjadi dasar dalam menentukan variasi perancangan ornamen yang dihasilkan. Hasil perancangan ornamen ini diharapkan dapat diaplikasikan dalam berbagai disiplin ilmu visual lain yang tidak melulu hanya menjadi produk kriya semata. Semangat mendaur ulang warisan budaya dan tradisi masa lalu untuk menjadi produk kreatif dengan inovasi modern menjadi bagian yang tidak bisa dipisahkan dari perancangan ini.
\end{abstract}

Kata kunci: perancangan, ornamen, Borobudur 


\section{PENDAHULUAN}

Setapak langkah diayunkan, budaya dan tradisi yang berbeda akan dijumpai. Itulah ungkapan yang sesuai dengan Indonesia. Ribuan pulau yang dipisahkan lautan menjadi batas terbentuknya tata kehidupan yang berbeda-beda. Jalinan panjang waktu yang ditempuh negeri ini dalam berakulturasi dengan pendatang dari daratan lain membawa kisah pengayaan sebuah tradisi dan budaya yang terbentuk. Keterbukaan dan kearifan dalam menyerap budaya seberang meninggalkan jejak artefak tradisi visual maupun lisan yang sangat kaya. Sebagai contoh adalah revitalisasi seni kriya di Jawa yang berlangsung beberapa kali (Sumartono, 2007). Keragaman budaya yang diwariskan karena persilangan budaya lokal dan seberang dengan tahapan waktu yang berbeda-beda, jelas sekali diurai dalam Lombard (2008), sejarawan dari Perancis. Hingga kini jejak warisan tradisi dan budaya yang mungkin susah untuk dihitung jumlahnya masih sangat lekat dengan masyarakat Indonesia dalam aspek kehidupan sehari-hari. Beragam motif batik pesisiran dan pedalaman di tanah Jawa hingga kini masih terus diproduksi meskipun dengan penyebaran dan pemanfatan yang sangat terbatas dibandingkan dengan jumlah penduduk. Kain tenun dengan motif beraneka ragam dari penjuru negeri juga memiliki nasib yang serupa. Masih banyak lagi warisan tradisi dan budaya yang keberadaannya nyaris tenggelam meskipun saat ini tampak nyata.

Kekayaan warisan budaya dan tradisi yang melimpah akan menjadi usang dan terpinggirkan tanpa sebuah itikad untuk menjadikannya layak tampil. Kemampuan menyeruak dalam mengisi sendi kehidupan modern, postmodern, dan global menjadikan seni tradisi dapat hidup mengikuti lajunya zaman (Gustami, 2007). Tantangan terberat pelaku industri kreatif saat ini adalah kemampuan menyuguhkan inovasi yang mengangkat seni tradisi dan budaya dengan wacana yang telah disebutkan sebelumnya sebagai produk kreatif yang memiliki karakteristik unggul. Tumbuhnya produk kreatif yang bermuatan tradisi dan budaya menjadi unique selling memberi peluang besar untuk mengembangkan materi lokal yang berlimpah tersebut. Sangat jelas ketika beberapa warisan budaya yang ada di negeri ini mendapat pengakuan dunia internasional dan bahkan menjadi perebutan sengit atas hak paten yang disandangnya, seperti batik dan lainnya. Munculnya nilai ekonomi terhadap ekspresi produk kreatif yang bernuansa lokal akan menjadi peluang yang sangat menarik apabila pengembangannya dapat selaras dengan ekpresi kehidupan masa kini. Produk kreatif yang disuguhkan tidak hanya memiliki fungsi sebagai cinderamata tetapi juga memiliki nilai guna. Pengembangan Batik Fraktal oleh anak-anak Bandung mampu mengawinkan seni tradisi dan budaya dengan kecanggihan teknologi. Seri cerita rakyat yang di tayangkan stasiun televisi sebagai sinetron berseri seperti "Angling Dharma", "Nenek Lampir", "Jaka Tingkir", dan lain sebagainya mampu mengemas produk kreatif lokal sarat tradisi dan budaya dengan tampilan baru melalui karakter media yang sangat diminati masyarakat dengan sekala lebih luas (Gustami, 2007).

Pundi-pundi warisan budaya Indonesia memiliki nilai yang sangat besar baik jumlah maupun value yang terkandung di dalamnya. Tragisnya, banyak masyarakat Indonesia yang tidak terlalu peduli dengan potensi itu. Banyak warisan budaya yang diakui oleh negara lain dengan hak paten internasional, sedangkan warganya sendiri tidak bisa berbuat apa-apa. Kelalaian atau ketidakacuhan memicu untuk lebih berhati-hati terhadap kekayaan budaya yang dimiliki. Kekayaan budaya yang begitu beragam hanya sedikit yang mendapatkan perhatian maksimal. Padahal, banyak sekali potensi budaya yang layak dan bahkan bernilai tinggi untuk dapat muncul sebagai ikon budaya yang menarik. Jika dicermati lebih dalam salah satu objek budaya yang ada, tentunya hal itu memiliki banyak dimensi potensi yang dapat diangkat setara dengan kekuatan dimensi yang biasa dikonsumsi. Kemauan untuk mengeksplorasi warisan budaya merupakan tanggung jawab bersama untuk menjadikan aset peninggalan tersebut mempunyai nilai guna yang maksimal untuk kepentingan bangsa. Kebanyakan mereka yang berusaha mengeksplorasi peninggalan budaya merekam objek apa adanya tanpa melakukan perubahan yang berarti. Sebagian lagi dari mereka berusaha melakukan perubahan yang cukup signifikan terhadap peninggalan budaya tesebut. 
Proyek perancangan ragam hias ornamen "Harini" tidak melakukan seperti dua hal tersebut, tetapi mencoba memanfaatkan objek budaya sebagai bagian dari inspirasi penciptaan. Secara fisik hasil dari penciptaan ini bukan merupakan kelanjutan dari peninggalan budaya yang sudah ada, melainkan menciptakan inovasi baru dalam media visual. Penggabungkan beberapa elemen visual ini diharapkan mejadi nuansa baru dalam penggalian objek budaya warisan masa lalu. Inovasi dalam penciptaan ini memungkinkan untuk mengeliminasi daya tolak terhadap produk budaya yang terkesan kuno karena penyelarasan tentang tren menjadi bagian utama dalam penggarapan produk budaya ragam hias pada short sarong. Selama ini kenyataan pahit selalu didapati karena daya tolak yang sangat tinggi terhadap produk budaya tersebut. Lemahnya daya gali untuk mengangkat objek budaya menyebabkan hal tersebut.

Sadar atau tidak, muncul keengganan untuk menggali seni tradisi dan budaya yang selama ini dianggap usang. Kondisi semacam ini menjadikan suguhan produk kreatif berkonten lokal memasuki pasar global sangat terbatas. Semangat individu masih menganggap sesuatu yang mencul dari barat bersifat superior, begitu juga sebaliknya. Masuknya kolonialisme Eropa dan Belanda pada abad ke-17 mampu menanamkan ekspresi estetika dan budaya barat untuk menduduki posisi dengan apresiasi teratas (Sachari, 2007). Indonesia menjadi bangsa yang inferior secara tidak sadar, sehingga produkproduk yang berlabel barat menjadi layak untuk diperebutkan dan mampu mendongkrak gaya hidup di kalangan masyarakat umum. Muncullah istilah Ori dan $K W$ sebagai penanda strata gaya hidup masa kini. Pengembangan inovasi produk tradisi dan budaya seharusnya mampu menjadi standar dalam mengonsumsi produk kreatif bahkan dengan kemampuan jual secara global. Kekayaan yang ditinggalkan nenek moyang bangsa Indonesia sangat beragam dan kaya jenisnya akan menjadi sia-sia jika semangat untuk merevitalisasi hal tersebut lemah.

Salah satu peninggalan arsitektural abad ke-9 yang kini menjadi kebanggaan Indonesia masih meninggalkan banyak misteri. Asal-usul keberadaannya hanya terekam singkat di beberapa artefak prasasti dengan informasi sangat terbatas. Banyak sejarawan dari dalam maupun luar negeri dengan teorinya mencoba menguak asal-usul bangunan spiritual Budhis terbesar dan tertua di dunia ini. Analisis Basya (2012), ahli metafisika Islam, menjadi bagian dari pengayaan teori yang mencoba mengungkap asal-usul Borobudur dari sisi yang berbeda. Bangunan yang lazim disebut Borobudur merupakan warisan dunia UNESCO dan pernah masuk ke dalam 7 keajaiban dunia, ditemukan pertama kali oleh Sir Stamford Raffles pada 1814 saat Inggris menduduki Indonesia dan dibantu seorang insinyur Belanda, H.C. Cornellius (Sujarweni, 2012). Teori yang umum dipakai adalah ketika Kerajaan Mataram kuno yang diperintah oleh raja dari dinasti Syailendra yang menganut kepercayaan Budha yaitu Samarotungga membangunan bangunan bertingkat yang sangat indah (Jinalaya) sebagai tempat suci peribadatan. Berdasarkan prasasti Kayumwungan (824 M) dan Tri Tepusan (842 M) peresmian Borobudur dilakukan oleh putri Samarotungga, yaitu Pramodawardhani (Soekmono, 1973).

Lepas dari masa lalunya yang masih simpang siur, Borobudur sebagai sebuah peninggalan besar meninggalkan banyak sekali warisan berupa artefak visual dengan balutan filosofi Budhis yang kental. Bangunan batu dengan 10 tingkat, 504 stupa, dan 1460 panel relief, menyisakan kekayaan simbol-simbol visual yang layak untuk diungkap (Sujarweni, 2012). Pengungkapan dengan tujuan spiritual, budaya, dan sejarah yang ujungnya dapat menjadi komoditas visual sebagai elemen penunjang produk kreatif, menjadi aktivitas berharga yang patut digalakkan. Keberadaan dan kebesaran Borobudur belum sebanding dengan eksplorasi komoditas kreatif yang mungkin dapat menjadi bagian dari penggerak devisa nonmigas.

Rumusan masalah dalam rancangan ini menitikberatkan pada permasalahan bagaimana merancang ragam hias baru dengan inspirasi simbol-simbol visual yang ada pada panel relief Latitavistara candi Borobudur dengan penggarapan visual menggunakan elemen flora. Perancangan ornamen "Harini" terinspirasi oleh beberapa karya terdahulu yang pernah diciptakan berkaitan dengan pengembangan ornamen dan warisan budaya. Semangat penggaliannya patut mendapat acungan jempol karena membawa dampak yang sangat berarti terhadap kelangsungan peninggalan tradisi dan 
budaya. Mereka adalah salah satu yang telah ikut berperan menggerakkan seni budaya dan tradisi menuju harkat yang lebih tinggi. Gerak langkah karya-karya tersebut dan keterkaitannya dengan perancangan ornamen "Harini" sekilas diuraikan sebagai berikut.

\section{Batik Fraktal}

Inovasi yang dilakukan terhadap peninggalan budaya batik dengan menggabungkan teori matematika dan teknologi menghasilkan perangkat lunak yang mampu menciptakan ornamen batik dengan mudah, disebut Batik Fraktal. Batik fraktal merupakan penemuan Pixel People Project, sebuah kelompok riset desain di Bandung. Kelompok ini didirikan Nancy Margried, Muhamad Lukman, dan Yun Hariadi. "Batik fraktal adalah motif batik tradisional yang ditulis ulang secara matematis," seperti didefinisikan dalam www.pxlpplproject.com. Motif fraktal ini diaplikasikan dengan menggunakan teknik batik tradisional atau dengan printer laser. Muhamad Lukman, Pixel People Project Research and Design Group; Yun Hariadi; dan Drs Achmad Haldani Destiarmand, M.Sn dari Fakultas Seni Rupa Institut Teknologi Bandung, menyatakan, batik itu sendiri membawa karakteristik fraktal. Pixel People Project mengembangkan perangkat lunak batik fraktal. Program berbasis Java ini memudahkan seorang pemula sekalipun untuk mengembangkan motif batik dalam formula fraktal. Hasil desainnya lalu disimpan dalam format png. Alhasil, kreativitas mereka ini mendapat penghargaan dari United Nations Education, Scientific, and Cultural Organization (UNESCO), badan Perserikatan BangsaBangsa, di bidang kebudayaan pada awal Oktober 2008. UNESCO menilai Batik Fraktal memiliki kualitas tinggi dan berpotensi besar di pasar internasional (Amri, 2009). Semangat untuk menjadikan "Batik" memiliki nilai lebih melalui inovasi yang dilahirkan, sangat menginspirasi dalam perancangan ornamen "Harini", untuk dapat memiliki semangat dan pencapaian yang sama.

\section{Batik Pohon}

Batik sebagai komoditi budaya nasional pergerakan produksinya masih berjalan pesat. Sangat mudah dijumpai produk batik di pasaran dengan beraneka ragam tampilan produk jadi. Dengan alasan kecepatan produksi dan kebutuhan warna yang beragam, batik sekarang diproduksi dengan menggunakan bahan pewarna kimia. Sebelum ditemukan pewarna kimia, batik diwarnai dengan zat pewarna yang diambil langsung dari alam. Di tengah pekatnya industri batik dan isu lingkungan, Candra Diana dan Suroso suaminya mengembangkan batik pewarna alam yang diberi merek "Batik Pohon". Warna yang digunakan semua murni dari berbagai jenis pohon yang tumbuh di Indonesia. Menurut Suroso, pewarna alam sangat aman terhadap pencemaran lingkungan yang dihasilkan dari limbah pewarnaan. Kayu mahoni yang diambil dari limbah pergergajian di Jepara, bahan kulit pohon relatif tidak terlalu bermasalah karena banyak persediaannya, kulit rambutan, akar mengkudu, kulit buah jalawe, dan kulit manggis bisa digunakan namun terkendala karena jatuhnya musim buah-buahan yang terbatas. Dengan menggunakan kain lokal seperti tenun Jepara, katun lokal hingga sutra, batik pohon mengembangkan motif flora selain motif pakem yang sudah ada. Pengembangan motif dalam pembuatan batik kadang disesuaikan dengan kebutuhan pasar yang ada, seperti batik Betawi yang mengangkat motif ondel-ondel. Dengan menghadirkan pewarna batik yang biasa dipakai nenek moyang masa lalu, Batik Pohon mampu membawa batik dengan nilai lebih sebagai produk kreatif masa kini. Motif Peacock Dancing karya batik pohon tidak hanya diaplikasikan pada kain semata, tetapi juga pada keramik perlengkapan minum teh. 

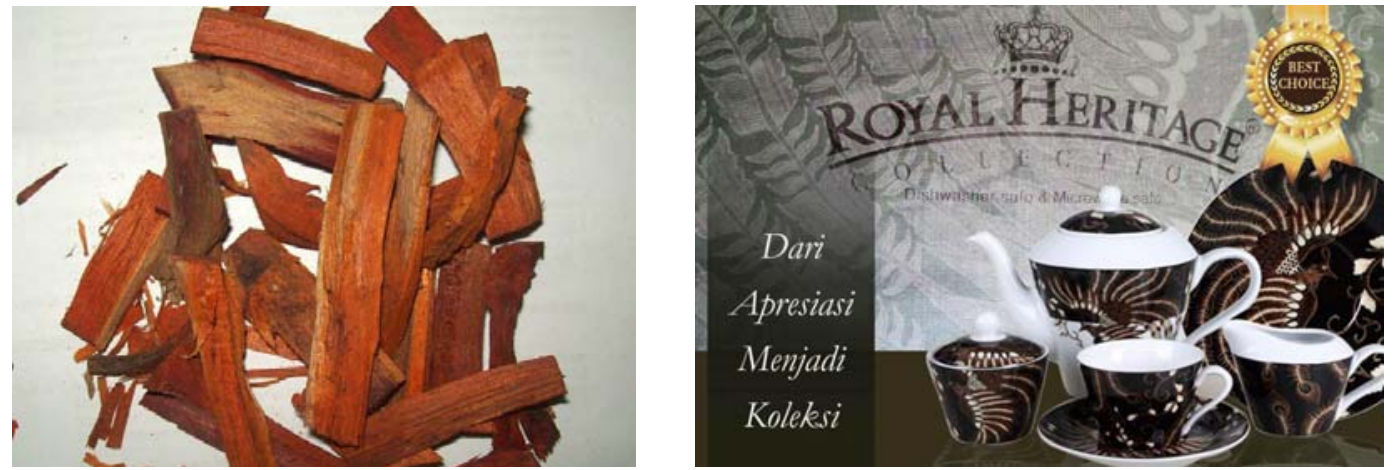

Gambar 1 kayu pewarna batik dan aplikasi motif Peacock Dancing

(Foto koleksi Batik Pohon)

Semangat menggali kekayaan lokal menjadi bagian dari komoditi produk kreatif yang memiliki kemampuan membangkitkan karakter bangsa menjadi tujuan utama dalam perancangan ini. Kasus perancangan ini lebih mengarah kepada menggali potensi Borobudur dari sisi lain sebagai warisan budaya yang memiliki nilai tinggi. Ada tiga manfaat yang ingin dicapai dalam perancangan ornamen "Harini" yang mengacu pada panel relief Latitavistara candi Borobudur, yaitu pertama, memberikan referensi baru kepada masyarakat untuk mengembangkan produk kreatif dengan menggunakan elemen ornamen "Harini" dalam perancanagan ini. Produk kreatif yang bertalian dengan pengembangan pariwisata atau citra produk indonesia dapat lebih spesifik menggunakan ornamen "Harini", karena digali langsung menggunakan landasan pijak visual maupun filosofis yang terkandung didalam artefak Borobudur. Kedua, sebagai bahan kajian budaya visual di dalam ruang lingkup akademik, menjadi pemicu lahirnya inovasi baru diseputar penggalian kreativitas melalui simbol-simbol visual yang terekam di dinding candi Borobudur dengan jumlah berlimpah. Kekayaan visual yang dimiliki Borobudur masih memerlukan banyak pelaku kreatif di lingkungan akademik yang rela melakukan studi dengan keberagaman kajian visual. Ketiga, secara pribadi perancangan ini tidak lepas dari keinginan yang mendalam untuk melakukan perancangan selanjutnya yang berorientasi pada perwujudan produk kreatif dengan menggunakan materi pendukung ornamen "Harini".

\section{METODE}

Metode perancangan yang dikemukakan Tom Kelley secara sistematis diawali dengan memahami, mengamati, memvisualisasikan, mengevaluasi, dan yang terakhir adalah menerapkan (Kelley, 2002). Paparan yang dikemukakan tersebut memiliki tolok ukur pendekatan kualitatif. Hal demikian sangat lazim digunakan dalam perancangan kreatif. Platform metode perancangan itu menjadi acuan perancangan ornamen "Harini". Lebih rinci berikut ini adalah uraian metode perancangan perancangan ornamen "Harini".

Memahami adalah menentukan batasan permasalahan untuk menggali data atau referensi visual berdasarkan kajian pustaka bergambar relief Latitavistara (Leber, 2011), data pendukung seputar luar lingkup struktur bangunan candi Borobudur (Miksie, 1991) dan filosofi simbol candi Borobudur (Kandahjaya, 1995). Mengamati yaitu melakukan seleksi visual untuk menentukan proses visualisasi, mulai dari proses pemilihan panel relief Latitavistara yang mengandung unsur flora hingga melakukan pengelompokan jenis flora yang sama kedalam kesatuan bentuk. Memvisualisasikan adalah proses rekayasa visual untuk mewujudkan tampilan bentuk dasar dari sebuah ornamen dari seluruh data visual yang telah ditetapkan sesuai dengan pengelompokannya. Mengevaluasi yaitu 
melakukan pengerucutan dalam pemilihan jenis flora yang mewakili untuk dilakukan penyederhanaan bentuk. Proses ini melibatkan kajian filosofis pendukung yang nantinya menjadi rujukan dalam penerapan atau penyusunan akhir ornamen. Kemungkinan pengembangan ornamen menjadi bagian yang tak terpisahkan dalam tahap ini. Terakhir, menerapkan, merupakan penyusunan akhir dari perancangan ornamen yang melibatkan penentuan pengembangan warna, bentuk, dan identifikasi penamaan dari munculnya varian ornamen. Metode perancangan ini mulai dari tahap visualisasi memungkinkan terjadinya proses black box atau penemuan tidak terduga melalui eksplorasi yang berlangsung.

\section{HASIL DAN PEMBAHASAN}

Seratus duapuluh panel relief Latitavistara (Leber, 2011) menggambarkan flora yang tumbuh di pulau Jawa, seperti: pohon mangga, kelapa, teratai, dan beberapa jenis pohon tropis yang lain. Penyusunan ornamen pada umumnya terinspirasi dari penyederhanaan elemen bentuk flora. Ornamen penghias panel relief maupun badan candi Borobudur atau kebanyakan bangunan candi yang lain juga menggunakan elemen flora.

Gambar 2 dan 3 menunjukkan proses penggalian visual (flora) melalui referensi panel-1 relief Latitavistara.

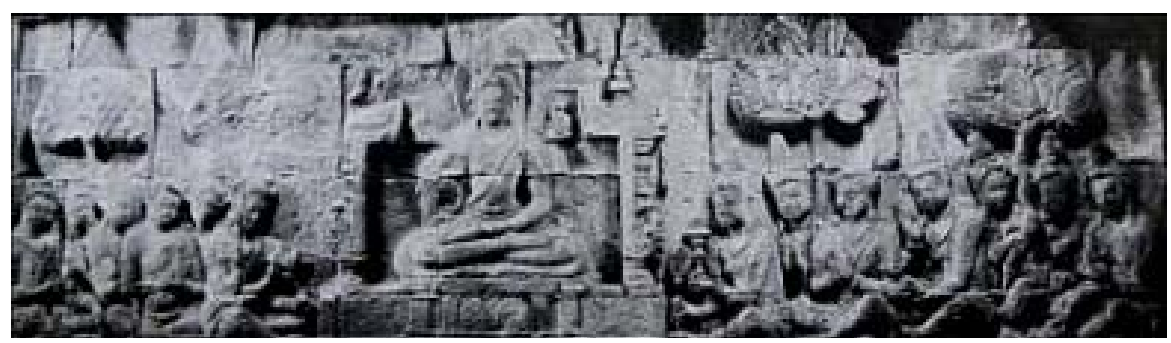

Gambar 2 Contoh Panel-1 relief Latitavistara

(Leber, 2011)
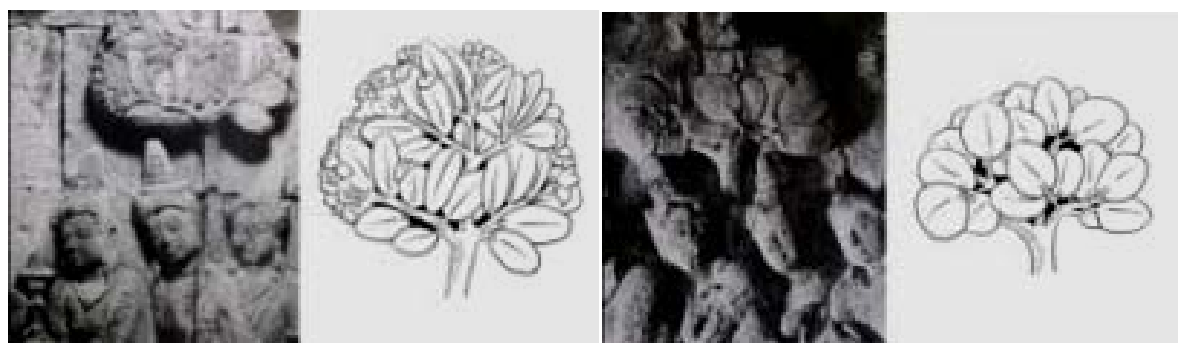

Gambar 3 Contoh transformasi visual Panel-1 relief Latitavistara

(Dokumentasi pribadi). 
Melalui pola yang sama seluruh panel relief yang berjumlah 120 buah ditransformasi visual, sehingga menghasilkan pengelompokan seperti gambar berikut.

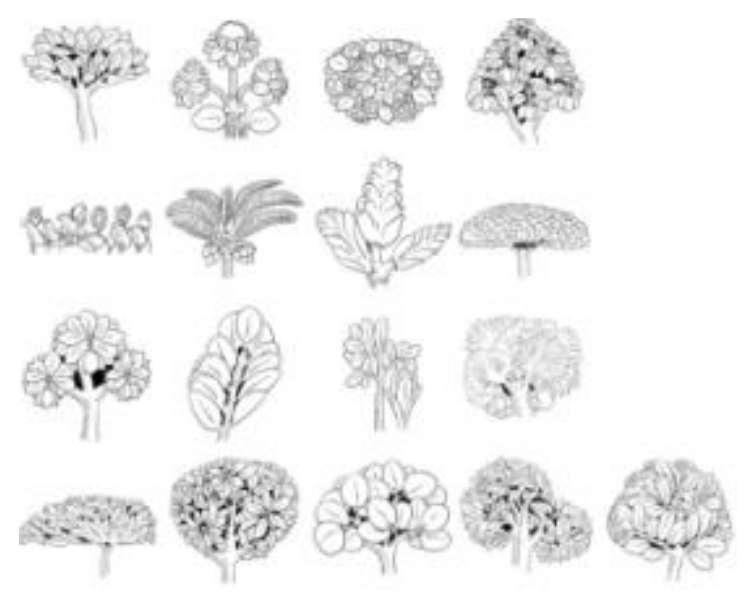

Gambar 4 Hasil dari transformasi visual seluruh panel Latitavistara (Dokumentasi pribadi)

Berdasarkan temuan visual yang ada, bunga teratai memiliki kuantitas yang paling tinggi dibandingkan dengan jenis flora yang lain. Bentuk dasar bunga teratai memiliki kesamaan dengan dengan harmonisasi bentuk melingkar Borobudur (Gambar 5) menggambarkan kemajemukan yang kokoh (Kandahjaya, 1995).



Gambar 5 Persamaan bentuk penampang Borobudur dan Teratai (Dokumentasi pribadi)

Tahap berikutnya dari perancangan adalah berupa penggabungan bentuk bunga teratai dan pola lingkaran Borobudur. Secara prinsip bentuk disederhanakan dalam pola geometris lingkaran dengan penyusunan melingkar, seakan mengitara stupa utama Borobudur atau kelopak bunga teratai (lihat Gambar 6). 

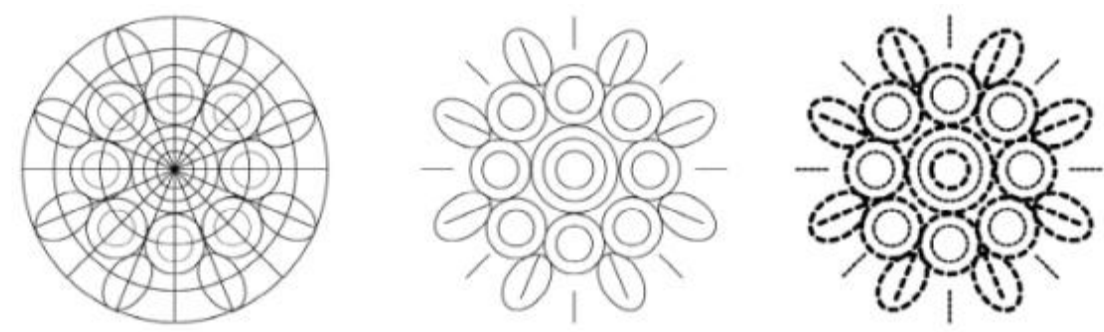

Gambar 6 Proses pembentukan pola dasar dari teratai dan Borobudur

(Dokumentasi pribadi)

Secara filosofis agama Budha, Borobudur menggambarkan kebajikan dan ketidakbajikan (Kandahjaya, 1995). Pola dasar di atas menggambarkan sebuah kebajikan atau kesucian sedangkan perlawanan dari sifat tersebut terangkum dalam rancangan di bawah ini. Sebuah simbol tanpa adanya pusat pencapaian, dan dibangun dari kepingan daun yang saling tarik menarik.
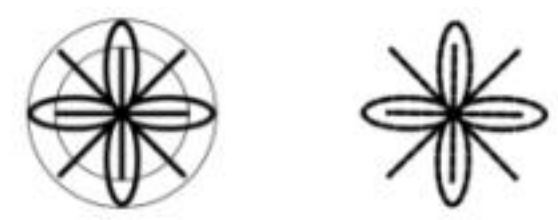

Gambar 7 Pola pendukung yang melambangkan ketidakbajikan (Dokumentasi pribadi)

Penggabungan pola dasar dengan pendukung untuk menciptakan rangkaian pola ornamen yang lebih besar, tidak lepas dari nuansa struktur bangunan candi Borobudur yang bersentral tunggal. Fenomena yang lazim terjadi pada susunan tatasurya dengan mataharinya, inti atom dengan proton, elektron dan netron, serta masih banyak lagi contoh yang bisa ditemukan di alam semesta ini.

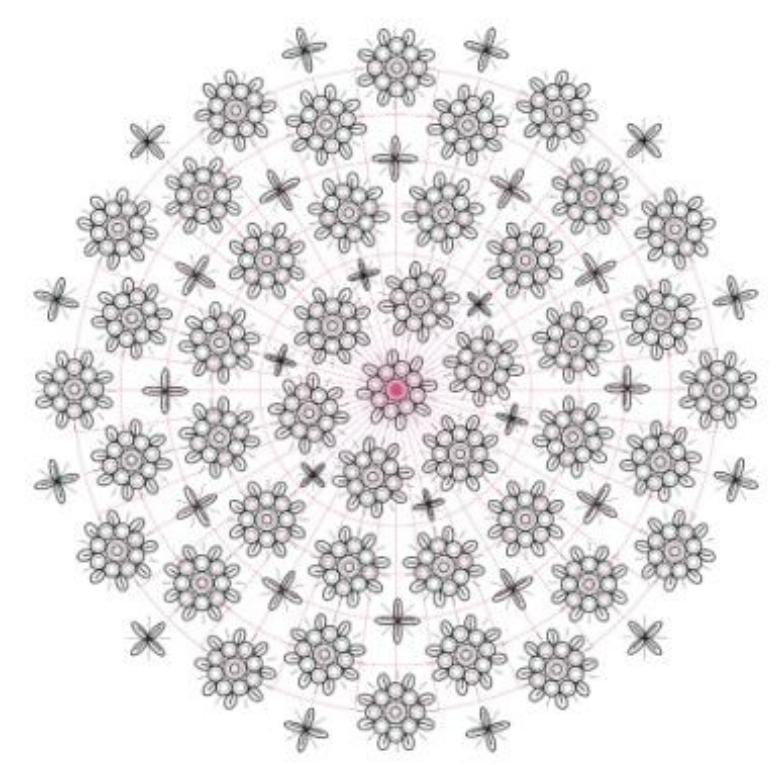

Gambar 8 Komposisi pola dasar dan pendukung (Dokumentasi pribadi) 
Sistem strata yang menyusun pola bertingkat bangunan candi Borobudur menjadi inspirasi menarik jika dikaitkan dengan pengembangan varian ornamen. Kamadhatu atau dunia hasrat, Rupadhatu atau dunia bentuk, dan Arupadhatu adalah dunia tanpa bentuk untuk mencapai nirwana merupakan kosmologi konsep madala yang diekpresikan Borobudur (Sujarweni, 2012).

Dalam rangkaian penggunaan nama, meminjam istilah dari bahasa Sansekerta, yaitu Harini yang berarti syair atau puisi. Pengertian khususnya dalam ornamen ini yaitu lebih kepada penggambaran liku kehidupan yang tertata kedalam untaian bait syair kebijaksanaan. Tiga nama dalam ornamen tersebuat adalah sebagai berikut. Pertama, Kamaharini; ornamen ini disimbolkan nafsu duniawi yang bergerak bebas dan diikuti oleh unsur lain sebagai bagian dari hingarbingar kehidupan yang menyajikan kefanaan. Komposisi ornamen sangat dinamis mengesankan kebebasan tanpa adanya batasan. Kamaharini adalah syair kehidupan yang diliputi oleh nafsu ingin memiliki tanpa mengerti apalagi memahami. Menggunakan warna cerah dengan saturasi lebih tinggi dibandingkan 2 edisi sesudahnya. Keceriaan yang tercermin masih bisa ditangkap meskipun mencoba mengacu pada warna alam dalam penekanan saturasinya. Kedua, Rupaharini; komposisi yang membangun struktur Rupaharini lebih tenang dibandingkan dengan struktur yang diperlihatkan pada ornamen Karmaharini. Rupaharini berarti syair kehidupan yang mengerti akan kebijaksanaan hidup. Menjalani kebijaksanaan untuk menyelesaikan waktu kehidupan tanpa tahu hakikat apalagi makrifat. Warna, menggunakan warna dengan saturasi sangat rendah. Meskipun ramai dengan bidang warna yang berbeda, Rupaharini masih dalam rangkaian tone yang senada. Konsep warna Rupaharini lebih tenang. Ketiga, Arupaharini; adalah syair menuju makrifat. Kemuliaan sehening nirvana dan kejayaan hanya untuk Yang Kuasa. Komposisi Arupaharini sangat tenang dan tersusun rapi. Pengendalian akan simbol nafsu duniawi mencapai puncak keselarasan. Nafsu hanya muncul untuk melayani Sang Penggelar Kehidupan. Adapun butiran permata yang terlihat di tengah ornamen melambangkan keberhasilan menggapai nirvana. Arupaharini ditempatkan pada penggunaan bahan dan eksekusi yang sangat mewah. Edisi Arupahari adalah edisi paling tinggi dari 2 ornamen sebelumnya. Tingkat keeksklusifannya menjadi daya tarik ornamen untuk dipergunakan dalam momen dan kebutuhan yang memiliki citarasa tinggi.
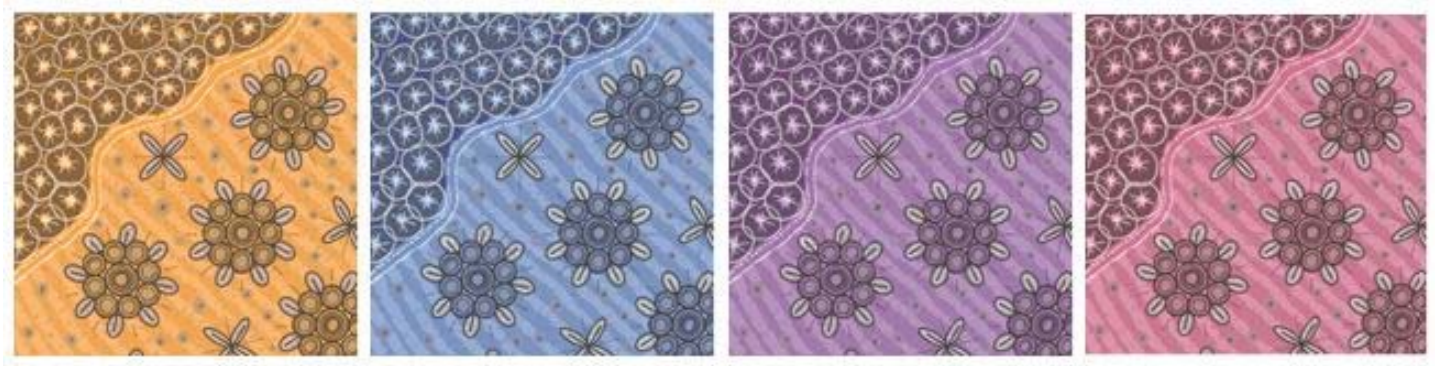

Gambar 9 Ornamen Kamaharini

(Dokumentasi pribadi)
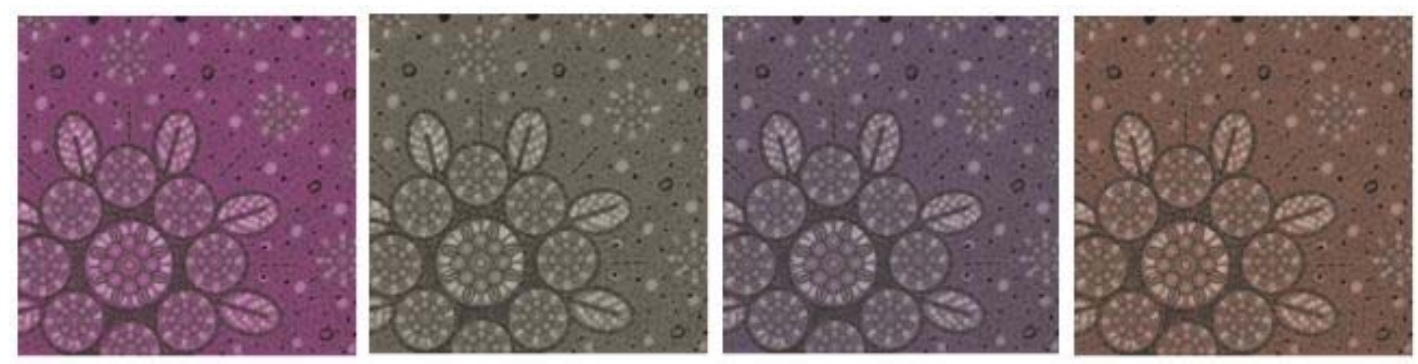

Gambar 10 Ornamen Rupaharini

(Dokumentasi pribadi) 

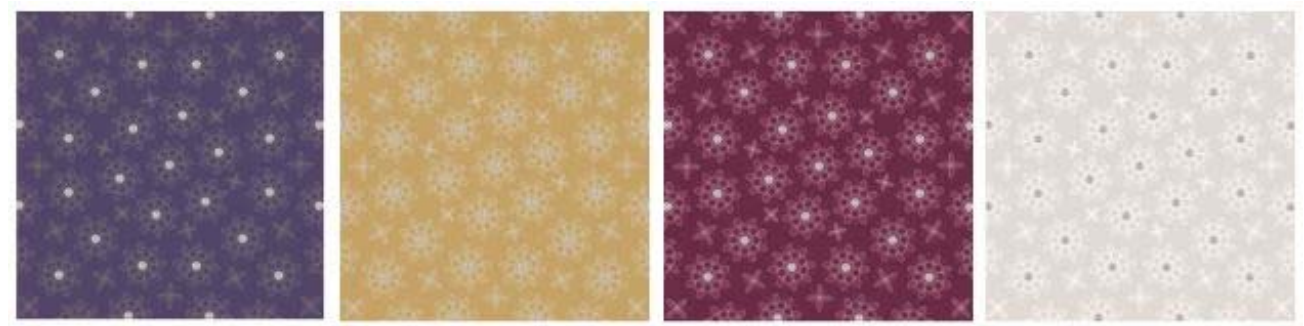

Gambar 11 Ornamen Arupaharini

(Dokumentasi pribadi)

Varian Gambar 9-11 merupakan standar bentuk dasar dari komposisi ornamen "Harini" yang masih sangat terbuka untuk dikembangan tanpa meninggalkan bentuk dasar penyusun komposisi. Berikut ini adalah contoh pengembangan ornamen "Harini" dengan pendekatan yang lebih bebas.
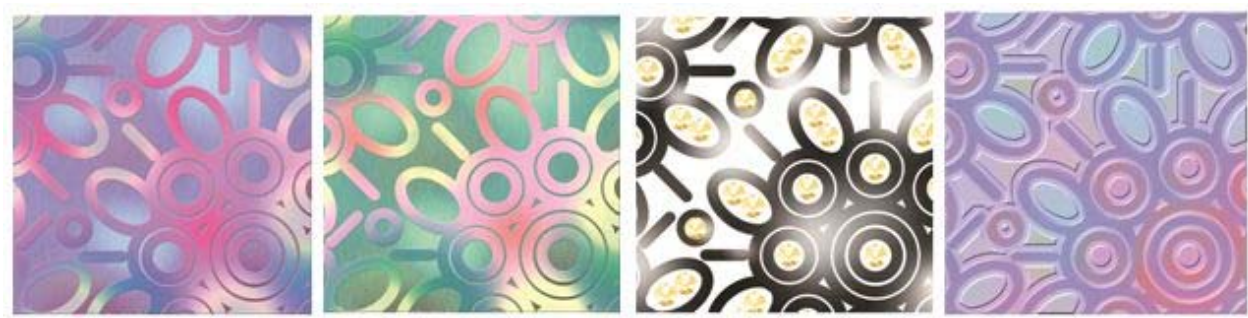

Gambar 12 Ornamen Harini dengan pengembangannya

(Dokumentasi pribadi)

Aplikasi lebih lanjut dari ornamen "Harini" dapat menunjang pengembangan produk kreatif, seperti: fesyen, grafis, produk, meubel, interior, dan lain-lain.

\section{SIMPULAN}

Panel relief Latitavistara yang terdiri dari 120 panel ternyata menyimpan beraneka jenis flora lokal, sehingga memudahkan proses pencarian bentuk dasar sebagai acuan pengembangan ornamen "Harini" yang kuat karakternya. Setrata religius bangunan candi Borobudur seperti Karmawibangga, Rupadatu, dan Arupadatu dapat menjadi inspirasi menyusun varian ornamen "Harini". Semangat tersebut tercermin dalam perancangan varian yang di berinama Karmaharini, Rupaharini, dan Arupaharini. Penggabungan dari penyederhanaan bentuk elemen flora dengan cara pengaturan dan penempatannya merupakan nafas dari terbentuknya pola dasar Ornamen "Harini".

Perancangan ornamen "Harini" terbagi menjadi dua pengembangan aplikasi pola standar dan modern. Pengembangan pola ornamen "Harini" ke dalam sentuhan modern memungkinkan ornamen tersebut dapat dieksplorasi sesuai dengan kebutuhan media dan tren yang diperlukan. Pada akhirnya ornamen "Harini" dapat memasuki industri global tanpa terpaku pada kaidah-kaidah yang membatasi seperti penggunaan warna, penggalian outline, penambahan elemen pendukung visual, dan lain-lain.

Hasil dari perancangan ornamen "Harini" tersebut dapat menjadi referensi visual bagi pelaku kreatif lain untuk diaplikasikan kedalam produk kreatif yang diciptakannya. Pada akhirnya Borobudur tidak hanya memberikan komoditi yang berupa tempat tujuan pariwisata, referensi penggalian sejarah, aktivitas keagamaan, tetapi juga produk kreatif yang memiliki karakter kuat Borobudur. 


\section{DAFTAR PUSTAKA}

Amri, A. B. (2009, 31 Jan). Matematika di Batik Fraktal. Diakses dari http://life.viva.co.id/news/read/26095-matematika_di_batik_fraktal

Basya, F. (2012). Borobudur \& Peninggalan Nabi Sulaiman. Jakarta: Ufuk Press.

Gustami, S. P. (2007). Butir-Butir Mutiara Estetika Timur. Yogyakarta: Prasista.

Kandahjaya, H. (1995). The Master Key for Reading Borobudur Symbolism. Jakarta: Kiraniya.

Kelley, T. (2002). The Art of Inovation. Jakarta: Gramedia.

Leber, T. (2011). Latitavistara. Jakarta: Kepustakaan Populer Gramedia.

Lombard, D. (2008). Nusa Jawa: Silang Budaya 2. Jakarta: Gramedia Pustaka Utama.

Miksie, J. (1991). Borobudur. California: Periplus.

Sachari, A. (2007). Budaya Visual Indonesia: membaca makna perkembangan gaya visual karya desain di Indonesia abad ke-20. Jakarta: Erlangga.

Soekmono, R. (1973). Sejarah Kebudayaan Indonesia 2. Yogyakarta: Kanisius.

Sujarweni, W. (2012). Jejak Candi Kuno Nusantara. Yogyakarta: Diva Press.

Sumartono. (2007). Revitalisasi seni kriya Indonesia. ARS: Jurnal Seni Rupa dan Desain, 5, 50-57. 